OPEN ACCESS

Edited by:

Giulio Munz,

University of Florence, Italy

Reviewed by:

Nehreen Majed,

University of Asia Pacific, Bangladesh

Alberto Mannucci,

University of Florence, Italy

${ }^{*}$ Correspondence:

David W. Graham

d.graham@ncl.ac.uk

Specialty section

This article was submitted to

Wastewater Management,

a section of the journal

Frontiers in Environmental Science

Received: 26 June 2017

Accepted: 26 January 2018

Published: 22 February 2018

Citation:

Bunce JT, Ndam E, Ofiteru ID, Moore A and Graham DW (2018) A

Review of Phosphorus Removal Technologies and Their Applicability to

Small-Scale Domestic Wastewater Treatment Systems.

Front. Environ. Sci. 6:8

doi: 10.3389/fenvs.2018.00008

\section{A Review of Phosphorus Removal Technologies and Their Applicability to Small-Scale Domestic Wastewater Treatment Systems}

\author{
Joshua T. Bunce ${ }^{1}$, Edmond Ndam ${ }^{1}$, Irina D. Ofiteru ${ }^{1}$, Andrew Moore ${ }^{2}$ and \\ David W. Graham ${ }^{1 *}$ \\ ${ }^{1}$ School of Engineering, Newcastle University, Newcastle upon Tyne, United Kingdom, ${ }^{2}$ Northumbrian Water Limited, \\ Durham, United Kingdom
}

The removal of phosphorus (P) from domestic wastewater is primarily to reduce the potential for eutrophication in receiving waters, and is mandated and common in many countries. However, most P-removal technologies have been developed for use at larger wastewater treatment plants that have economies-of-scale, rigorous monitoring, and in-house operating expertise. Smaller treatment plants often do not have these luxuries, which is problematic because there is concern that $\mathrm{P}$ releases from small treatment systems may have greater environmental impact than previously believed. Here P-removal technologies are reviewed with the goal of determining which treatment options are amenable to small-scale applications. Significant progress has been made in developing some technologies for small-scale application, namely sorptive media. However, as this review shows, there is a shortage of treatment technologies for P-removal at smaller scales, particularly sustainable and reliable options that demand minimal operating and maintenance expertise or are suited to northern latitudes. In view of emerging regulatory pressure, investment should be made in developing new or adapting existing P-removal technologies, specifically for implementation at small-scale treatment works.

Keywords: domestic wastewater treatment, decentralized systems, phosphorous, EBPR, photo-bioreactors, physico-chemical processes

\section{INTRODUCTION}

Phosphorus (P) releases due to anthropogenic activity promote eutrophication in aquatic ecosystems. For example in the UK, the main sources of $\mathrm{P}$ entering rivers are sewage effluent and agricultural run-off (Bowes et al., 2015) with up to $70 \%$ being attributed to sewage discharges (EA, 2015). This reality has resulted in tightening P discharge standards and increased pressure on the water industry to reduce $\mathrm{P}$ loads entering rivers, particularly to ecologically sensitive locations (EC, 2000; UKTAG, 2013). As such, targeted P-removal has become increasingly common in large, urban wastewater treatment plants (WWTPs). However, sensitive watercourses also can be in more remote locations, receiving P discharges from smaller WWTPs. Further, wastewater from smaller communities is often treated less rigorously (Molinos-Senante et al., 2014; Lutterbeck et al., 2017) and the potential negative impacts of $\mathrm{P}$ release from small treatment works may be underestimated (Bowes et al., 2015; May et al., 2015). 
The removal of $\mathrm{P}$ from wastewater can be performed using physico-chemical methods, biological treatment, and/or combinations of both, and many large-scale techniques are well established (Yeoman et al., 1988). However, translating such technologies to effective use at smaller scales has rarely been done and, as such, there is little information regarding the implementation and-or success of such systems. Small-scale treatment plants are different in that they may be less accessible than larger urban facilities; influent flows tend to be much more variable and subject to wider seasonal fluctuations; they are less rigorously managed and monitored; and wastewater composition often differs from urban sources. However, recovering $\mathrm{P}$ from WWTP effluent has high value, especially with growing Plimitation on global scales (see Figure 1). Nevertheless, this aspiration may not be economically or logistically feasible in small WWTPs, given traditional P-recovery technologies.

Within this context, here we examine currently available and also emerging P-removal processes for possible application at smaller scales. For this review, we consider any WWTP with a population equivalent of $<250\left(\sim 50 \mathrm{~m}^{3} /\right.$ day in the $\mathrm{UK})$, to be "small". This size implies lower maintenance, more variable feed-flow conditions and usually rural and/or remote sites (see Figure 2). The review first describes different treatment technologies used at larger scales and associated mechanisms of $\mathrm{P}$ removal. The paper then considers which mechanisms might be exploited to deliver reliable $\mathrm{P}$ removal in smaller

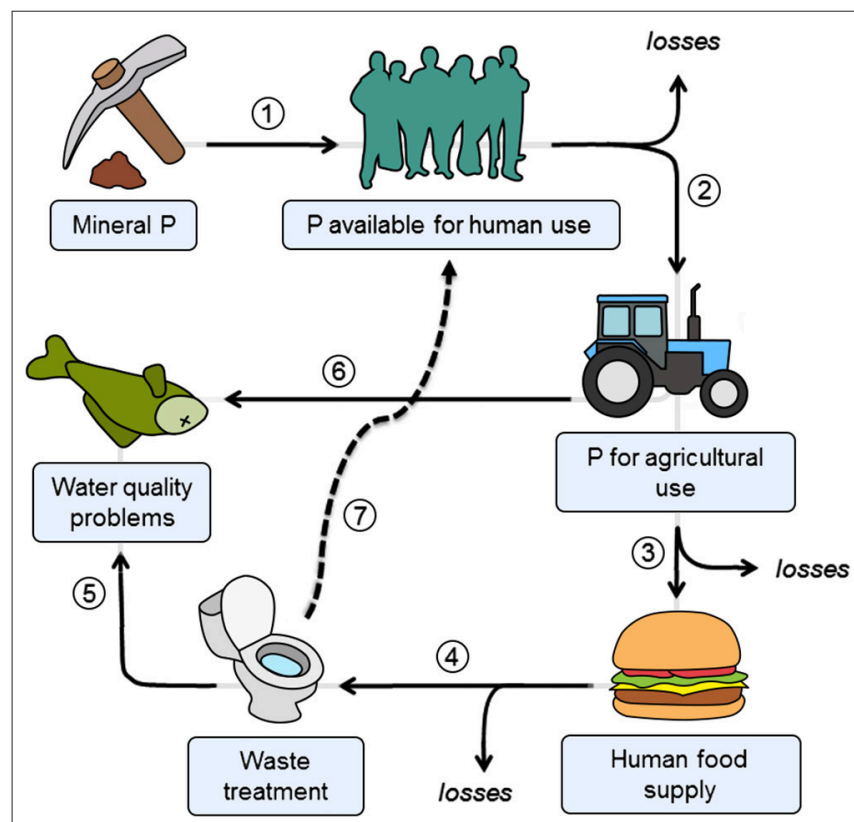

FIGURE 1 | Human P cycle. Solid lines denote the following flows: (1) mining of naturally occurring P mineral; (2) use of P for agriculture (e.g., in fertilizers); (3) $P$ use in food (e.g., as a constituent or preservative); (4) P in human excreta; (5) $\mathrm{P}$ discharged to the environment as a result of inefficient P-removal in wastewater treatment; (6) $\mathrm{P}$ in agricultural run-off resulting in diffuse pollution (6). Dashed lines show the material flow option that closes the cycle via P recovery from wastewater (7). Losses are Adapted from Childers et al. (2011). systems, including Enhanced Biological P removal (EBPR), algalbased processes and passive, physico-chemical mechanisms, analyzing their pros, cons and their underpinning science. Finally, recommendations are made relative to directions for new work, especially research and development needed to create sustainable P removal in smaller systems in the future.

\section{PHYSICO-CHEMICAL PHOSPHORUS REMOVAL OPTIONS}

Physico-chemical processes of $\mathrm{P}$ removal have been used for $\mathrm{P}$ control for many years. Such processes are generally reliable and effective, however, they are not without limitations. For example, some can affect the $\mathrm{pH}$ of the effluent, many require addition of chemicals before final discharge, and physico-chemical solutions often need additional processing steps due to the production of extraneous solids during treatment (Cornel and Schaum, 2009). Most processes include precipitation, sorption and/or ion exchange mechanisms, which are summarized below.

\section{Chemical Dosing to Promote P-Precipitation}

The most common chemical P-removal options involve dosing metal salts to either pre-treated influent, conventional activated sludge (CAS) reactors, or to the outlet from the secondary clarifier (Cornel and Schaum, 2009; Oleszkiewicz et al., 2015).

\section{Mechanism of P-Precipitation}

The added salt (e.g., trivalent metal salts, ferric chloride) precipitates $\mathrm{P}$ in the wastewater and resulting solids residuals are removed either by settling under gravity or by filtration. Whilst resulting precipitates may be rich in $\mathrm{P}$, separation of chemically-bonded $\mathrm{P}$ can be difficult, making efficient P-recovery unlikely for further use (Oleszkiewicz et al., 2015). This presents a disadvantage over biological $\mathrm{P}$ removal systems because it limits the economic benefits of downstream uses for the Prich sludge. Although work has been performed to provide more controlled precipitation (e.g., as struvite) (Le Corre et al., 2009) and several commercial solutions exist, such approaches have had variable success. Further, P removal rates are typically proportional to the mass of chemical added, which impacts the amount of extra solids produced; therefore, there are intrinsic cost-benefits to the amount of salt used and the method of solids separation used. P effluent concentrations of $1 \mathrm{mg} / \mathrm{L}$ can be achieved by conventional gravity settling (Burton et al., 2014). However, stricter effluent standards will generally demand more sophisticated separation techniques.

\section{Application of P-Precipitation and the Management of Solids}

It has been suggested that due to several bi-reactions, the amount of salt required to achieve the desired $\mathrm{P}$ removal rate is greater than the stoichiometric ratio and up to double (Whalley et al., 2013). Thus, the solids production associated with chemical dosing may present an interesting sustainability issue. Unlike larger-scale sites, small-scale treatment works may not have the space or infrastructure to support on-site sludge 


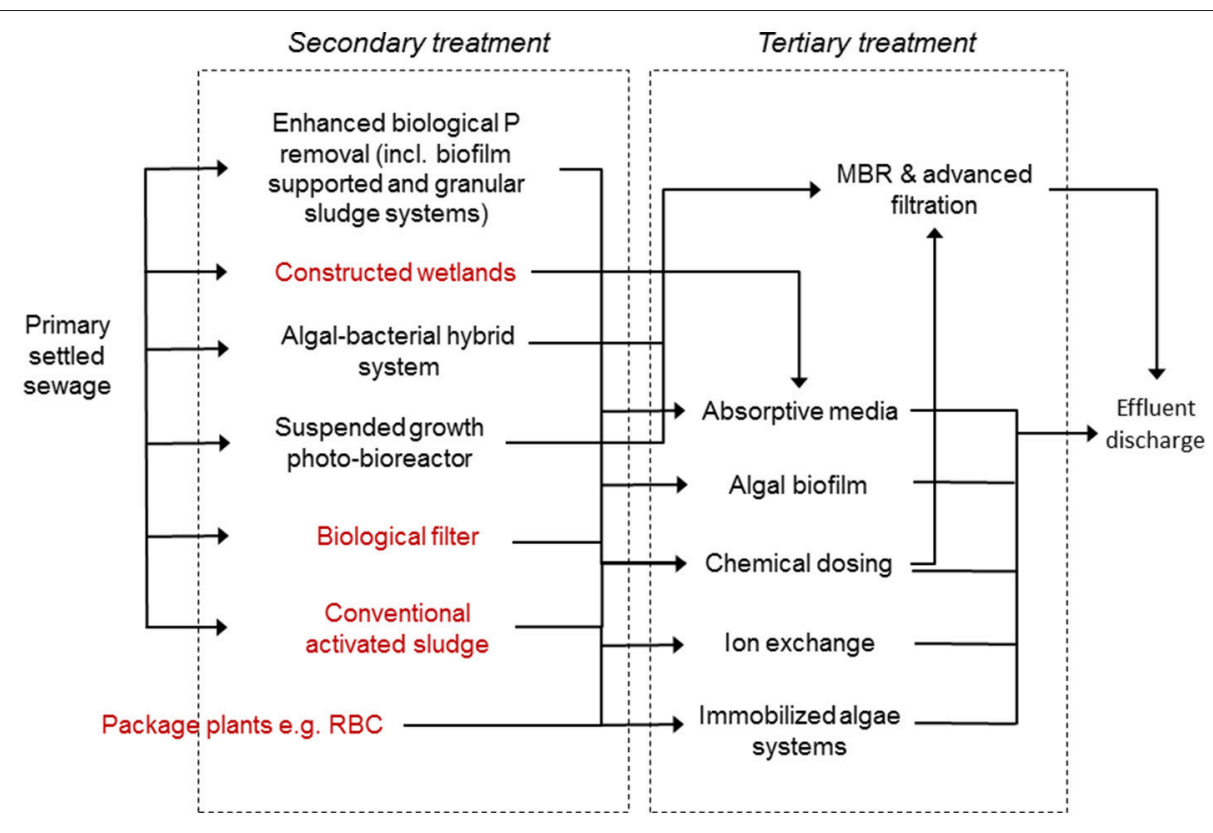

FIGURE 2 | Possible P treatment options for application at small-scales. Technologies in red are more often found in smaller or decentralized treatment locations.

management. Therefore, sludge must be transported to regional sludge management facilities and the environmental cost-benefit of such activities must be analyzed. One benefit of extra sludge production is the opportunity for biogas production through anaerobic digestion. It has been suggested, however, that the use of chemical-rich sludge may limit biogas productivity (Parsons and Smith, 2008). This is of particular concern at small-scale treatment works where sludge production is likely to be relatively low (even with chemical dosing) and so the productivity of the digestion must be maximized to warrant the environmental and economic cost associated with sludge transport and management.

Techniques including filtration and tertiary-ballasted flocculation, are sometimes combined with metal salt dosing to achieve lower P effluent levels with less salt addition. Recent advances (e.g., Mitchell and Ullman, 2016; Wang et al., 2018) in the use of such technologies have suggested total phosphorus (TP) concentrations of $<0.05 \mathrm{mg} / \mathrm{L}$ can be achieved. However, this was only possible with long hydraulic residence times within the coagulation tanks and the use of multi-phase tertiary treatment solutions.

Chemical dosing is generally reliable and widely accepted, therefore it is the most commonly used P-treatment option. However, it is unsuitable for small-scale plants for various reasons. First, footprints for chemical storage and accessibility for regular deliveries may be limited. Further, variability of the influent $\mathrm{pH}$ at small works is not widely reported, and the effectiveness and reliability of $\mathrm{P}$ removal may be difficult to predict. This is particularly relevant because of "shock loading" phenomena typically observed at small-scale treatment systems (Chong et al., 2011). Whilst this could, in some cases, be somewhat mitigated against by the use of flow balancing tanks, there is no "one-size-fits-all" solution due to space or infrastructure constraints often associated with small-scale systems. Additionally, $\mathrm{pH}$ adjustment, typically using sodium or potassium hydroxide, is often needed with metal salt addition, creating operating complexity and skill, which is often not available in small-scale systems. Finally, handling and storage of caustic substances and excess solids generated as a consequence of metal salt additions makes chemical precipitation by itself typically impractical for smaller scale applications.

\section{Absorptive Media for P-Removal}

In recent years, much work has been done to improve $\mathrm{P}$ removal in filter systems using active media (e.g., Drizo et al., 2006; Shilton et al., 2006; Gustafsson et al., 2008; Herrmann et al., 2014). In contrast to traditional filtration systems, reactive media filters rely on $\mathrm{P}$-sorption properties of certain materials to remove $\mathrm{P}$ in a targeted manner from wastewater (Arias et al., 2003), rather than using filter media solely for attachment of biomass. Absorptive media are manufactured from either, natural products (e.g., apatite, bauxite or limestone), industrial waste products (e.g., flyash, ochre or steel slag) or man-made products (e.g., Filtralite ${ }^{\mathrm{TM}}$ ). There are several commercially available products of which the most widely studied is Polonite. Renman and Renman (2010) report a phosphate removal rate of $91 \%$ when using Polonite to treat municipal wastewater over 1 year with a P-sorption capacity of $120 \mathrm{~g} / \mathrm{kg}$. However, the performance of such materials over longer periods requires more investigation. For example, Shilton et al. (2006) report significantly reduced P-removal in the latter portion of their 10-year study.

\section{Mechanisms of P-Sorption}

$\mathrm{P}$ is removed by filter media by the process of sorption or by direct precipitation. Briefly, this involves the movement 
of inorganic P from the wastewater to the surface or body of reactive components (e.g., calcium or iron) contained in the media, where is accumulates (Brix et al., 1999). The $\mathrm{P}$ removal capacity is therefore, dependent on the mineral content of the media. Early work on P removal by sorptive media focussed on the use of locally sourced sands and gravel (e.g., Mann and Bavor, 1993). More recently, the development of a wide variety of natural or man-made materials has advanced the potential for the application of this technology at small-scale.

\section{Application of Absorptive Media}

Much work has focused on reducing the footprint and enhancing the functionality of processes that include P sorption mechanisms, such as in constructed wetlands (Brix et al., 1999; Drizo et al., 1999; Arias et al., 2003; Arias and Brix, 2004; Vymazal, 2007); a treatment option with potential for P-removal at smaller scales (Herrmann et al., 2014). Constructed wetlands are favorable as $\mathrm{P}$ uptake can be achieved through microbial and plant uptake, in addition to adsorption by media (Vymazal, 2007; Reddy et al., 2010). While the removal of $\mathrm{P}$ in wetlands without the use of absorptive media is restricted to $40-60 \%$ (Vymazal, 2007), such systems are fairly well understood and flexibility in configurations means that they may be suitable for a wide range of applications, being able to achieve the simultaneous removal of multiple contaminants (beyond just $\mathrm{P}$ ).

The advantages of "adsorptive" wetlands include the potential for low operational maintenance, an "aesthetically" pleasing planted wetland, and the ability of such systems to also reduce biological oxygen demand (BOD) and ammonium levels (Drizo et al., 1999). Therefore, wetlands constructed with sorptive filter media can provide a holistic treatment solution and in this regard are comparable with EBPR systems (see section Biological Phosphorus Removal Options), with the removal of multiple contaminants by a combination of precipitation, microbial activity and plant uptake.

In their extensive review of wetland media for P removal, Vohla et al. (2011) found that industrial by-products and some man-made media provide the best $\mathrm{P}$ sorption capacity, the former being more desirable from a sustainability perspective. It is noted, however, that constructed wetlands often require a continuous flow of water (Massoud et al., 2009), which may limit their application in very small-scale applications. The use of balancing tanks may go some way to negate this, within the constraints of space and cost. Further, the optimal loading rate for many sorptive media is not known (Vohla et al., 2011). In an effort to overcome this problem as well as to broaden the potential application, sorptive media has been incorporated into standalone filtration systems (Arias et al., 2003; Renman and Renman, 2010). Such applications share the advantages of other modular systems where they can be maintained or replaced without disruption to the rest of the treatment process.

In spite of the potential that filter media presents for effective $\mathrm{P}$ removal, there are some substantial limitations to the technology. The primary cause for concern is the influence on $\mathrm{pH}$ and the costs associated with correcting this. Recent work to thermally or chemically pre-treat media to overcome this hurdle presents promise (Yin et al., 2017), however, the approach has not yet been proven at full-scale or over a sustained period of time.

\section{Ion Exchange Technologies}

Ion exchange technologies are well established and used in many contexts, including desalination and the deionization of water (Awual and Jyo, 2011). The principle of ion exchange also can be applied to the removal of $\mathrm{P}$ from wastewater and some suggest the technology may be particularly suitable for use at decentralized locations (Zhao and Sengupta, 1998). Whilst not as widely studied or applied as other physico-chemical P removal methods, the highly selective nature of some exchange media means that their consideration is warranted.

\section{Mechanisms of Ion Exchange for P Removal}

The predominant form of $\mathrm{P}$ in wastewater effluent is anionic. Phosphate ions are reversibly interchanged between the liquid wastewater and the solid ion exchanger, offering simultaneous removal and recovery (Martin et al., 2009). Immobilised particles of a metal cation typically form the polymer exchange base, termed a polymeric ligand exchanger, on to which P-selective nanoparticles (e.g., ferric oxide) are placed (Zhao and Sengupta, 1998). This approach causes the selection for $\mathrm{P}$ anions in wastewater over other "competing" ions, such as sulfates or chlorides. This traditionally proves difficult due to the relatively low abundance of phosphate ions in wastewater effluents, compared to competing species.

\section{Application of Ion Exchange for P Removal}

Performance of traditional ion exchangers is governed by the valence and weight of the ion in question, but due to relatively low concentration of phosphate ions in wastewater, early attempts to implement the technology were unsuccessful (Nesbitt, 1969). More recent attempts have improved efficiency through pretreatment of ion exchange media, for example with ferric oxide or aluminum hydroxide, to increase selectivity for phosphate ions and has resulted in P-removal rates of $80-90 \%$ (Martin et al., 2009; Seo et al., 2013).

Ion exchange systems have the advantage of delivering Precovery through post-treatment of the sorption media (Martin et al., 2009). Whilst high $\mathrm{P}$ removal rates have been achieved at laboratory scale, implementation at the full-scale has been limited due to the requirement for expensive chemical addition for the recovery of $\mathrm{P}$ and the sensitivity of some media to $\mathrm{pH}$ conditions (Zhao and Sengupta, 1998; Sendrowski and Boyer, 2013). However, the work of Seo et al. (2013) has suggested that certain ion exchange materials offer potential, with the addition of a single chemical solution required for regeneration of the media. Nevertheless, much work is required for this technology to be proven at full-scale, especially under variable flow regimes. Further, chemical requirements and cost may make this technology unfeasible for use for small-scale and-or rural treatment works because chemical reinstatement is probably impractical in such scenarios.

In summary, physico-chemical processes offer the confidence of reliable P removal and simplicity of operation. However, the long-term sustainability of current technologies has not 
been well demonstrated, especially related to the operation and maintenance of small-scale systems. This means they may not be viable for small-scale WWTPs unless they are coupled with other processes, such as those that have been promoted with wetland options. That is to say, physico-chemical P removal systems can generally be considered effluent "polishing" treatment solutions, offering little or no additional contaminant removal. Whilst this alone does not prohibit their application at small-scales, options that provide more holistic treatment of wastewater should be given due consideration, for example, biological P removal.

\section{BIOLOGICAL PHOSPHORUS REMOVAL OPTIONS}

Biological P removal, especially Enhanced Biological Phosphorus Removal (EPBR) with activated sludge systems, has been studied in depth in recent years. It is considered to be a cost effective and environmentally sustainable alternative to chemical treatment (Acevedo et al., 2012; Nguyen et al., 2013). However, EPBR also is reputed as not being wholly reliable due to fluctuating performance and high dependence on skilled operators resulting in difficulty in process control (Seviour et al., 2003). This alone potentially may mean it is less suitable for downscaling for use at decentralized treatment works (Brown and Shilton, 2014), but with its growing range of applications and continual advancements in efficiency and reliability, it deserves consideration of implementation at small-scales. Further, EBPR systems offer great potential where space may be limited and multi-functioning systems may be desirable.

There is a growing understanding of the biochemical mechanisms associated with luxury P-uptake, which rely upon phosphorus-accumulating organisms (PAO) for EBPR. Although not fully understood, operating conditions, including prerequisites for metabolism, such as carbon, glycogen and electron acceptor requirements are being adjusted to promote the growth and proliferation of PAOs. The influence of these factors likely becomes more prevalent in smaller works where flows and, therefore, organic and nutrient loads are lower and more variable. Here follows a brief summary of current understanding of the biochemistry and microbiology of EBPR, which must be considered when down-scaling this treatment approach.

\section{Identification of PAO}

Biological P-removal primarily occurs via the accumulation of P by microorganisms beyond "normal" requirements for metabolic processes (termed luxury uptake). P accumulation is as polyphosphate and is retained as an energy reserve for maintenance or to provide a competitive advantage over ordinary heterotrophs (Nicholls and Osborn, 1979). For this reason, PAOs tend to outcompete other organisms under many conditions. The exception is in the presence of Glycogen Accumulating Organisms (GAO), which metabolize volatile fatty acids (VFAs) or other carbon compounds in a similar way to PAO, but do not accumulate P (Cydzik-Kwiatkowska and Zielinska, 2016). GAOs are not discussed in detail here, but it should be noted that their co-existence is a common reason for poor performance in EBPR systems (Oehmen et al., 2007).

Candidatus Accumulibacter phosphatis (Accumulibacter) is the most widely studied PAO and is this basis of most metabolic models (Crocetti et al., 2000; Garcia Martin et al., 2006; Oehmen et al., 2007). Their taxonomy is now well understood with Garcia Martin et al. (2006) obtaining a complete genome of Accumulibacter, which has provided insights into gene expression involved in key metabolic processes. Furthermore, Accumulibacter are considered the prevalent PAO in effective in EPBR systems (Zeng et al., 2003; López-Vázquez et al., 2008), although other PAO are present too.

For several years, Acinetobacter sp. were reported to be the organism primarily responsible for EBPR (Crocetti et al., 2000; Li et al., 2003; Nguyen et al., 2011). Their function as a PAO was later disproved and Accumulibacter was identified as the PAO most commonly dominant in EBPR systems. The tetrasphera-related Acintobacteria sp. have also been found in high abundance in well performing P-removal systems and proven to carry out luxury $\mathrm{P}$ uptake (Oehmen et al., 2007; Nguyen et al., 2011). They appear to be less well understood that Accumulibacter, particularly with regard to metabolic processes. However, it is known that they generally accumulate more complex carbon sources, such as amino acids and proteins, under anaerobic conditions which they store as an unidentified substance (Günther et al., 2009). For this reason, it cannot be said that Acintobacteria sp. metabolize according to existing models and further work is required to fully understand their functionality as PAOs.

Other putative PAOs have been found in varying lowlevels at P-removal wastewater treatment plants. These include Pseudomonas sp., Paracoccus sp. and some Enterobacter sp. (Li et al., 2003; Krishnaswamy et al., 2009).

Certain PAO can simultaneously carry out P-accumulation and denitrification under alternating anaerobic-anoxic conditions (Kuba et al., 1993; López-Vázquez et al., 2008). Denitrifying PAO (DPAO) use nitrate as the sole terminal electron acceptor instead of oxygen for the oxidation of PHA under anoxic conditions (Kuba et al., 1996; Zeng et al., 2003). Promoting DPAO in WWTPs has possible benefits over separate $\mathrm{P}$ and $\mathrm{N}$ removal systems (Oehmen et al., 2007), such as energy savings. Furthermore, it has been shown that DPAO have similar P-removal capabilities as regular PAO under most circumstances (Kuba et al., 1993).

\section{Metabolism of PAO}

The growth of PAO can be promoted through optimisation of operating conditions, such as cycling anaerobic and aerobic/anoxic phases, which may be amenable to some small-scale treatment processes. An early metabolic model describing the behavior of PAO under such conditions was proposed by Comeau et al. (1986). Details are as follows and summarized in Figure 3. Under anaerobic conditions, PAO uptake VFA by secondary transport and store them as PHA (Smolders et al., 1995). Energy for this process is obtained from ATP, formed from the hydrolysis of internally stored polyphosphate or the degradation of glycogen. The breakdown of the polyphosphate causes a release of orthophosphate into 


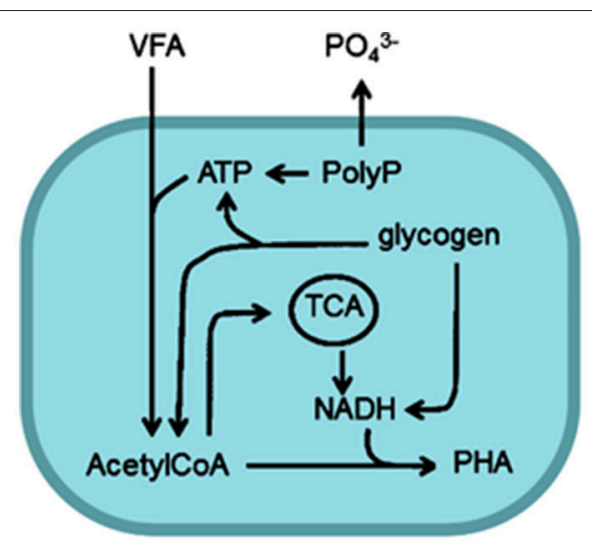

Anaerobic conditions

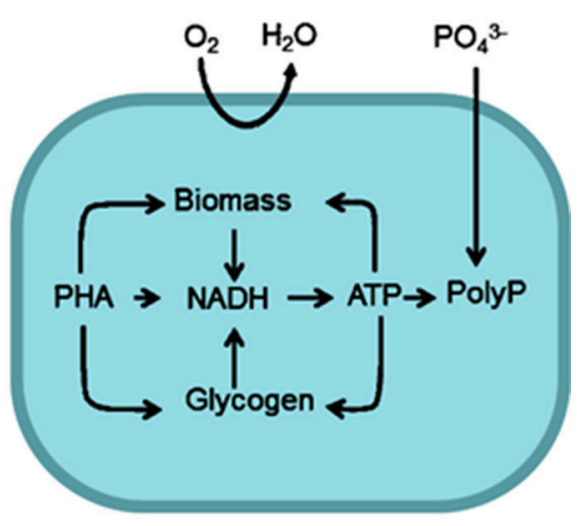

Aerobic conditions

FIGURE 3 | Metabolic pathways of PAO under aerobic and anaerobic conditions. PHA, polyhydroxyalkanoate; PolyP, polyphosphate.

the bulk liquid (Comeau et al., 1986; Smolders et al., 1994) (see Figure 3). The synthesis of PHA under anaerobic conditions requires the reduction equivalent $\mathrm{NADH}$, which is provided either by the TCA cycle (Comeau et al., 1986; Wentzel et al., 1986) or by Glycolysis (Smolders et al., 1994). Martin et al. (Garcia Martin et al., 2006) confirmed that the genes required for both pathways exist within Accumulibacter sp. and it has since been shown that PAO are capable of utilizing both the TCA cycle and Glycolysis (Zhou et al., 2009). Some have suggested that some PAO may switch between metabolic pathways according to internal or external conditions (Acevedo et al., 2012, 2014; Majed et al., 2012; Lanham et al., 2013). Utilisation of glycolysis has been shown to yield more efficient P-removal rates than the TCA cycle, within the context of an enhanced CAS system (Lanham et al., 2013).

In contrast, in the aerobic phase, accumulated PHA is oxidized by an available electron acceptor and the subsequent energy release is used for the uptake of $\mathrm{P}$ (with stabilizing cations) and synthesis of glycogen (Acevedo et al., 2012). A net accumulation of $\mathrm{P}$ is achieved since a greater amount of $\mathrm{P}$ is taken up in the aerobic phase than is released as orthophosphate during the anaerobic phase (Comeau et al., 1986; Smolders et al., 1994).

\section{Traditional EBPR Systems and Recent Enhancements}

EPBR has traditionally been applied within conventional activated sludge (CAS) systems. Much work has been done on optimizing configurations for continuous-flow systems for Premoval and understanding the effects of physical parameters on system performance (Mino et al., 1998; de-Bashan et al., 2004; Oehmen et al., 2007). More recently, research has been focussed on two areas: (1) the identification of the effects of operational and environmental parameters on the microbial diversity and metabolic behavior of the community and (2) the effect of the integration of biofilm carriers on system performance.

In addition, there are several other reports that are particularly noteworthy as having extended the knowledge relating to EBPR.
It is now commonly accepted that the level of biological Premoval is directly proportional to the number of PAO present in the system. In their extensive study, Mao et al. (2015) found Accumulibacter in 17 waste water treatment works from six different countries and, on average, it made up to $7.0 \%$ of the total biomass. This result is significant because only six of the treatment works they screened were configured for EBPR, suggesting that the potential for effective EPBR is more driven by local environmental conditions than by specific "engineered" microbial communities. Carvalheira et al. (2014) and Acevedo et al. (2014) support this by showing PAO adapt their metabolic processes to optimize substrate utilization, making them more resilient than previously believed.

Recent applications of EBPR include incorporation in membrane bioreactors (MBR), granular sludge reactors, and sequencing batch biofilm reactors (SBRs). Inclusion of EBPR in MBRs, whether SBRs or continuous-flow, has proven successful in achieving high levels of P-removal from municipal wastewater. MBRs offer a number of advantages including the retention of solids within the reactor, which results in a high mixed liquor suspended solids concentrations without the need for a large system footprint ( $\mathrm{Ng}$ et al., 2000). High levels of Total $\mathrm{N}$ and COD removal also have been reported in recent studies (Shin et al., 2014; Zhang et al., 2014), and combining MBR with a University of Cape Town (UCT) configuration EBPR system has led to reports of P-removal rates of up to $88 \%$ and final effluent levels of $0.3 \mathrm{mg} / \mathrm{L}$ total P (Monclus et al., 2010; Smith et al., 2012; Sun et al., 2013). Johir et al. (2015) recently reported that without inclusion of the UCT approach, total P-removal by MBR was only 53\%, which further confirms that luxury $\mathrm{P}$ uptake by bacteria is unlikely without alternating anaerobic-aerobic/anoxic conditions.

The advantages of superior effluent quality and small physical footprint make the use of an MBR attractive for any size of treatment plant, including small works. However, membrane fouling continues to be an issue and as such, they 
require a higher level of maintenance (Gander et al., 2000; LeClech et al., 2006). Furthermore, the capital cost of MBR systems is perhaps one reason why implementation of the technology has been somewhat limited to date, including at smaller scales, and whilst the cost may reduce as the popularity of the technology grows, at present it may be a prohibitive factor for decentralized applications. There has been limited work done to assess the performance of small-scale MBRs (Gander et al., 2000; Chong et al., 2011) and, while conclusions are generally positive, the need for further study is apparent to assess the true cost-benefit of the technology for small-scale application.

Granular sludge reactors have been developed to operate under aerobic or anaerobic conditions. Aerobic granulated sludge is a suspended biofilm-like technology that relies on the growth of biomass on granules rather than employing flocculation as in CAS plants. The lower operating footprint of SBR systems resulting from the lack of independent settling tanks (Bindhu and Madhu, 2013) means that they are gaining popularity for the simultaneous removal of $\mathrm{COD}, \mathrm{NH}_{3}$ and $\mathrm{P}$ (De Kreuk et al., 2005; Pronk et al., 2015). A commercial application of this technology is the Nereda ${ }^{\circledR}$ system, which have achieved P-removal rates up to $87 \%$ in full-scale plants (Pronk et al., 2015).

Whilst such commercial systems are not marketed for use at small-scale works, their benefits of a smaller footprint, no settling tanks, and relatively high levels of P-removal means that they deserve consideration. However, whether such systems are operationally simple enough or P-removal is reliable over a sustained period of time must also be considered. Furthermore, there are no reports to our knowledge on the effects of highly variable flows, which is common in smaller works, on the performance of AGS systems.

Sequencing batch biofilm reactors are still considered a relatively novel treatment technology (Mielcarek et al., 2015); however, they are growing in reputability. The growth carrier may be fixed, a moving bed or in suspension. All options offer the advantages of up to $50 \%$ higher biomass retention than activated sludge, the lack of requirement for sludge settling, and the space saving achieved through the use of a single reactor tank (Garzon-Zuniga and Gonzalez-Martinez, 1996; Jabari et al., 2014); advantages that may favor use at small scale works.

EBPR has been reported in fixed-carrier sequencing batch biofilm reactors on a number of occasions, although observed removal rates have been variable, a $>90 \%$ Total P-removal rate was reported at lab scale by Gieseke et al. (2002), Li et al. (2003), and Yin et al. (2015), whereas an average between 70 and 90\% has been reported elsewhere (Garzon-Zuniga and GonzalezMartinez, 1996; Rahimi et al., 2011). Further, some suggest an additional carbon source or chemical precipitation are needed to achieve low effluent P levels (Pastorelli et al., 1999; Wang et al., 2006). The importance of effective biomass removal-through backwashing or otherwise-and the detrimental impact on EBPR if not effectively implemented, has been reported on a number of occasions (Morgenroth and Wilderer, 1999; Arnz et al., 2001; Mielcarek et al., 2015). This is of importance when considering the requirement for minimal operational maintenance, which is desirable at small and/or remote works. Whilst this technology has been implemented at full-scale, it is apparent that consistent levels of $\mathrm{P}$ removal have not yet been achieved a factor that would need to be overcome before implementation within tightly regulated environments. Furthermore, the behavior of PAO within biofilms is not well understood, particularly with regards to interactions among species and its effect on nutrient removal (Kesaano and Sims, 2014).

\section{Novel and Potential EBPR Systems}

Recent advancements in the development of newer technologies for P-removal are summarized in Table 1. Whilst there is much work to be done to assess the scalability of such systems, the potential of each to perform reliable P-removal at small-scales systems is considered here.

New, complex configurations of MBR systems have been developed with the aim of optimizing nutrient removal. One such example is the sequencing batch moving bed membrane bioreactor system developed by Yang et al. (2010), which achieved a Total P-removal rate of $84 \%$. Whilst such developments offer potential, the reliability and consistency of such technologies to remove $\mathrm{P}$ to very low levels has not been proven, even at lab-scale. Further work is required to establish reliability of these technologies, particularly using a range of influent strengths. Moreover, the capital, operational and environmental costs associated with the application of such novel technologies should be assessed; not least for use at small-scale works.

One novel development for granular sludge is single systems operated under anaerobic-anoxic conditions for $\mathrm{P}$ removal. The technology, known as AnoxAn, has the aim of achieving simultaneous multi-nutrient removal (Díez-Montero et al., 2016). The up-flow nature of this system provides space and cost savings in terms of mixing and energy requirements (Lettinga et al., 1980), making it potentially attractive for biological Premoval. Total P-removal rates of $89 \%$ have been achieved using AnoxAn reactors without compromising total $\mathrm{N}$ removal, but with the need for mechanical mixing (Díez-Montero et al., 2016).

Membrane Aerated Biofilm Reactors (MABR) are a novel modification of the MBR technology discussed previously. They are based on the transfer of a gaseous electron donor or acceptor across a hydrophobic membrane (Ivanovic and Leiknes, 2012; Nerenberg, 2016) and have only recently been use as a commercial product, which is not established within the nutrient removal market (Martin and Nerenberg, 2012). MABRs behave differently to conventional biofilms due to the presence of gas exchange, adding a layer of complexity to the treatment process (Martin and Nerenberg, 2012). They have been successfully commercialized for $\mathrm{N}$ removal and recent studies report total $\mathrm{P}$ removal of up to $90 \%$ when used with an SBR (Sun et al., 2015). The technology shows potential in terms of energy efficiency and reduced maintenance requirements (Nerenberg, 2016), but much work is required before their use for EBPR is proven at fullscale. Further, the requirement for gas storage may mean the technology is unsuitable for use in decentralized locations even if EBPR can be shown to be successful in real-life settings. Finally, the whole-life costs associated with full-scale application requires further investigation.

In summary, there has been considerable advancement in existing technologies as well as the emergence of several novel 
TABLE 1 | Examples of novel P-removal technologies and relative performance at different scales.

\begin{tabular}{|c|c|c|c|c|}
\hline Technology & Description & $\begin{array}{l}\text { TP-removal rates } \\
\text { (unless specified) }\end{array}$ & Phase of development & References \\
\hline \multicolumn{5}{|l|}{ ALGAL SYSTEMS } \\
\hline \multirow[t]{2}{*}{ Algal biofilm reactors } & Fixed growth algal bioreactors & $41-97 \%$ & Bench-scale & $\begin{array}{l}\text { Sukacova et al., } 2015 \\
\text { Kesaano et al., } 2015 \\
\text { De Godos et al., } 2009\end{array}$ \\
\hline & & Not reported & Full-scale & Boelee et al., 2014 \\
\hline Immobilised algae & Algal species are immobilised as beads or to sheets. & $62-90 \%$ & Bench-scale & $\begin{array}{l}\text { Shi et al., } 2007 \\
\text { He and Xue, } 2010 \\
\text { Gao et al., } 2015\end{array}$ \\
\hline $\begin{array}{l}\text { Suspended growth } \\
\text { photo-bioreactors }\end{array}$ & Suspended growth algal bioreactors & $61 \%$ & Pilot-scale & Min et al., 2011 \\
\hline $\begin{array}{l}\text { Membrane photo biofilm } \\
\text { reactors }\end{array}$ & $\begin{array}{l}\text { Membrane bioreactors with algae seed; operating } \\
\text { promote phototrophic growth }\end{array}$ & $66-97 \%$ & Bench-scale & $\begin{array}{l}\text { Xu et al., } 2014 \\
\text { Ruiz-Martinez et al., } 2012 \\
\text { Praveen and Loh, } 2016\end{array}$ \\
\hline Osmotic MPBR & Osmotic membrane photo-bioreactor & $90-100 \%$ & Bench-scale & $\begin{array}{l}\text { Chen et al., } 2014 \\
\text { Luo et al., } 2015\end{array}$ \\
\hline \multicolumn{5}{|l|}{ EBPR SYSTEMS } \\
\hline MBR-UCT & $\begin{array}{l}\text { Membrane bioreactor integrated into a } \\
\text { continuous-flow EBPR }\end{array}$ & Up to $88 \%$ & Full-scale & $\begin{array}{l}\text { Sun et al., } 2013 \\
\text { Smith et al., } 2014\end{array}$ \\
\hline $\begin{array}{l}\text { Sequencing batch moving } \\
\text { bed membrane bioreactor }\end{array}$ & $\begin{array}{l}\text { Sequencing batch reactor with integrated } \\
\text { membrane, moving-bed Carriers }\end{array}$ & $84 \%$ & Bench-scale & Yang et al., 2010 \\
\hline MB-SBBR & Moving bed sequencing batch biofilm reactor & $97 \%$ & Bench-scale & Yin et al., 2015 \\
\hline \multirow[t]{2}{*}{ SBBR } & Sequencing batch reactor with fixed biofilm & $90 \%$ & Bench-scale & Rahimi et al., 2011 \\
\hline & & $70-90 \%$ & Pilot-scale & $\begin{array}{l}\text { Li et al., } 2003 \\
\text { Gieseke et al., } 2002\end{array}$ \\
\hline Granular sludge & $\begin{array}{l}\text { Advanced activated sludge process operated as } \\
\text { SBR }\end{array}$ & $87 \%$ & Full-scale & Pronk et al., 2015 \\
\hline MABR-SBR hybrid & $\begin{array}{l}\text { Membrane aerated biofilm reactor operating in } \\
\text { combination with a sequencing batch reactor }\end{array}$ & $90 \%$ & Bench-scale & Sun et al., 2015 \\
\hline AnoxAn & Vertical flow anaerobic-anoxic reactor & $89 \%$ & Bench-scale & Díez-Montero et al., 2016 \\
\hline \multicolumn{5}{|c|}{ PHYSICO-CHEMICAL SYSTEMS } \\
\hline \multirow[t]{2}{*}{ Active filter media } & $\begin{array}{l}\text { Naturally occurring or man-made materials that } \\
\text { remove } \mathrm{P} \text { through precipitation or absorption. }\end{array}$ & 95\% (PO4) & Bench-scale & $\begin{array}{l}\text { Drizo et al., } 2006 \\
\text { Gustafsson et al., } 2008\end{array}$ \\
\hline & & $77-91 \%$ & Full-scale (other) & $\begin{array}{l}\text { Shilton et al., } 2006 \\
\text { Renman and Renman, } 2010\end{array}$ \\
\hline lon exchange & & 80-90\% & Bench-scale & $\begin{array}{l}\text { Seo et al., } 2013 \\
\text { Martin et al., } 2009\end{array}$ \\
\hline
\end{tabular}

EBPR systems in recent years. The relative sustainability of biological removal of $\mathrm{P}$ continues to make them attractive for many applications. Novel technologies offer potential for high levels of P-removal with some even achieving efficient P-removal over sustained periods of time at various scales. However, such systems succeed at the cost of operational complexity and/or high energy consumption. Therefore, although alternating anaerobicaerobic/anoxic conditions are possible in smaller systems, greater operating and maintenance requirements probably exclude them for use at small scales.

\section{ALGAE-BASED AND HYBRID TREATMENT OPTIONS}

The use of microalgae systems for the treatment of wastewater is now well established (Martínez, 2000; Shi et al., 2007); however, its full-scale application for nutrient removal is more limited, especially at higher latitudes.

\section{Mechanisms of Algal P Removal}

$\mathrm{P}$ is an essential nutrient for algal growth and under certain conditions, algae will uptake $\mathrm{P}$ in excess of growth requirements (Larsdotter, 2006; Powell et al., 2009). Under such circumstances, $\mathrm{P}$ is taken up as orthophosphate and stored as polyphosphate granules for use as a growth reserve for when there is a lack of $\mathrm{P}$ in the environment (see Figure 4). Where inorganic orthophosphate is unavailable, algae will uptake organic P, converting to orthophosphate at the cell surface via the enzyme phosphatase (Larsdotter, 2006). Algal treatment solutions are typically either closed or open suspended systems, or biofilm systems, most commonly using flat-bed or tubular orientations (Hoh et al., 2016). However, much of the work done to understand the metabolism of $\mathrm{P}$ by algae has been related to 


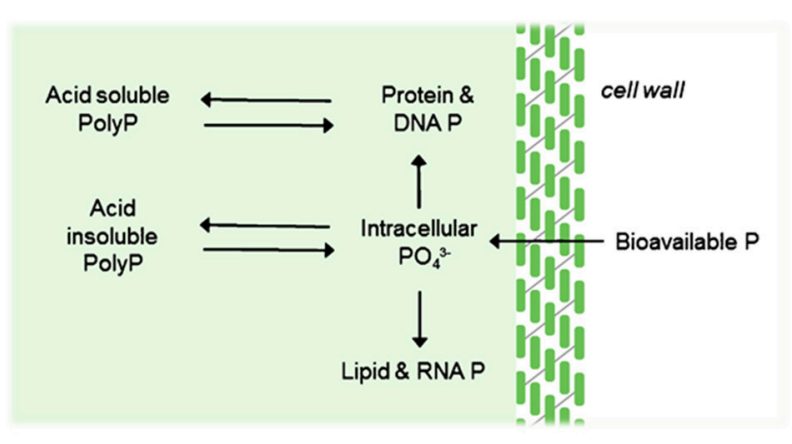

FIGURE 4 | P fluxes and storage pools associated with algal cells.

waste stabilization ponds. Within these contexts, only $15-30 \%$ P-removal is reported with significant variations as a function of temperature (Powell et al., 2009), which is unacceptable for targeted P-removal, especially for temperate or cooler climates.

\section{Application of Algal P Systems}

The green microalga Scenedesmus sp. and Chlorella sp. are known to carry out consequential luxury $\mathrm{P}$ uptake in the natural environment (Azad and Borchardt, 1970) and they have been reported to show effective removal of $\mathrm{P}$ from wastewater in a variety of contexts (Gonzalez et al., 1997; De-Bashan et al., 2002; Shi et al., 2007; He and Xue, 2010). For example, high levels (up to $90 \%$ ) of P-removal has been achieved by the immobilization of these microalgae on synthetic substrate, either sheets or as beads (Shi et al., 2007; Wei et al., 2008; He and Xue, 2010). Microalgal biofilm photobioreactors have also shown effective Premoval (97\% Total P-removal) in recent testing (Sukacova et al., 2015). Although there is a lack of literature on upscaling algal biofilm systems from laboratory to full scale, particularly for the use of nutrient removal from municipal wastewater (Kesaano and Sims, 2014), the potential of such systems warrants their consideration.

Algal biofilm systems, as with bacterial biofilms, present a possibly option for small-scale treatment locations due to their resilience to changes in environmental conditions and ability to retain biomass (Sun et al., 2015; Praveen and Loh, 2016). For example, Sukacova et al. (2015) achieved P removal rates of up to $98 \%$ using a biofilm photobioreactor treating real wastewater. In contrast, Kesaano et al. (2015) reported Premoval rates of only $41 \%$ from a cultured algal biofilm, although $\mathrm{N}$ removal was up to $100 \%$, suggesting $\mathrm{N}$ may have been limiting in their systems. De Godos et al. (2009) reported $80 \%$ $\mathrm{P}$ removal using a promising algal photo bioreactor operating under controlled lighting conditions, treating high strength pig slurry.

Additional work is required to determine the potential of such systems at larger scales, over prolonged periods of time, and with domestic wastewater. Interactions among organisms in mixed-culture photo-biofilms also are not well understood (Kesaano and Sims, 2014; Ramanan et al., 2016). However, as knowledge is gained, process optimisation may be possible, especially using biofilm systems to achieve higher $\mathrm{P}$ removal rates using low-energy light and minimal chemical requirements. Despite gaps in basic understanding, there are a few commercially available algal biofilm technologies that have been designed specifically for nutrient removal from municipal wastewater [e.g., Clearas Advanced Biological Nutrient Recovery $\left.\left(\mathrm{ABNR}^{\mathrm{TM}}\right)\right]$.

Algal MBR systems have been piloted using an algal seed to potentially optimize nutrient uptake from low carbon wastewater with membrane photobioreactors. The seed was the known Paccumulating algae Chlorella sp. and was assessed in laboratory scale pilots. Average Total P-removal rates between 66 and 97\% were reported under varying reactor configurations (RuizMartinez et al., 2012; Xu et al., 2014; Praveen and Loh, 2016). The potential of the technology at lab scale appears promising, although algal MBR has not been successfully operated at pilotscales under temperate or cooler conditions.

An osmotic membrane photobioreactor is a further enhancement of the membrane photobioreactor, developed with the specific intention of reducing membrane fouling (Achilli et al., 2009). It incorporates a selectively permeable membrane across which water flows under osmotic pressure rather than the positive pressure gradient used in a standard MBR (Huang and Lee, 2015; Praveen and Loh, 2016). The combination of membrane rejection and microbial assimilation can result in high $\mathrm{N}$ and P-removal rates under relatively energy-efficient operating conditions. A number of recent studies have reported organic carbon removal of between 87 and 99\%; phosphate removal of between 90 and 100\% and nitrogen removal between 62 and 97\% (Nguyen et al., 2013; Luo et al., 2014). Interestingly, the studies that reported very high (>95\%) P-removal, reported lower rates of $\mathrm{N}$ removal (Chen et al., 2011). Even with more advanced technologies, simultaneously delivering high levels of $\mathrm{N}$ and $\mathrm{P}$ removal (or full denitrification in sequence) remains complex and difficult.

Overall, algal systems offer the potential for high levels of nutrient removal (De Godos et al., 2009). Biofilms-based systems are of particular interest due to their ability to retain higher levels of biomass, resulting in space saving and greater resilience; both factors that are favorable in small-scale application. Coupled with the high levels of P-removal achieved at laboratory scale and the availability of low energy and easily controlled artificial lighting (Glemser et al., 2016), the use of phototrophic biofilm systems should be considered an attractive option for delivering P-removal at small-scale treatment systems.

However, this technology is still in its infancy for use at higher latitudes. Relative performance of algal biofilm systems over longer periods of time and under varying flow regimes, particularly at pilot and full-scales, has not been conclusively demonstrated. Further, the separation of solids from biofilm sloughing requires high-cost processes, such as centrifuging or filtration, which needs deeper investigation. While recent work suggests natural flocculants can be used to improve settling (e.g., Gutiérrez et al., 2015), it has not been proven beyond pilot scale, and the storage and management of such chemicals may not be feasible at a small-scale treatment works. 


\section{CONSIDERING P-REMOVAL TECHNOLOGIES FOR USE AT SMALLER SCALES}

Two critical considerations must be assessed while choosing a treatment technology: affordability-what the purchaser is willing or able to pay for what product-and appropriateness-the social and environmental factors associated with the installation and operation of the system (Grau, 1996). In light of ever tightening discharge standards, regulatory pressure is also becoming an important factor when reviewing the appropriateness of a technology.

A few key factors must be taken into account when considering a range of existing and emerging technologies for delivering P removal at small scale works. The first among the factors is the requirement to remove up to $90 \%$ of incoming $P$ load to meet current discharge consents of 1-2 mg/L P. Within typical WWTPs, approximately 10 and 30\% P-removal can achieved via solids settling and biological metabolism, respectively (Cornel and Schaum, 2009). Therefore, an additional $50 \%$ removal of $\mathrm{P}$ is required, assuming $2 \mathrm{mg}-\mathrm{P}$ per person per day contribution (Gilmour et al., 2008). As such, most novel P removal systems do not deliver adequate performance.

Further, it is likely that a small-scale system will be remotely located without major civil infrastructure. As a result, to sustain operational efficiency, it is critical that any technology implemented in rural and remote locations requires minimal maintenance. This can only be made a reality if the system is rapid to stabilize and simple in terms of construction and operation. The use of absorptive filter media within the context of a constructed wetland or as a standalone system is a promising solution on these bases. However, significant capital outlay, space considerations, and long-term sustainability may limit these options. In addition, the reliability of P-removal using active media over extended periods of time in full-scale applications is not proven. Finally, on smaller sites where space may be the limiting factor, the periodic reconstruction of a wetland may not be feasible. As such, a standalone system for P-removal by absorptive media may be preferable in such circumstances. To make such systems a viable option, further research is needed to determine the long-term effectiveness of such systems for smaller scale treatment applications and the performance of absorptive media under rapid fluctuations in flow and nutrient loadings.

Another consideration that impacts downsizing is sludge handling. Technologies with low sludge production are desired at small-scale systems to minimize storage and transport costs. Whilst optimizing the production of sludge from larger treatment works is beneficial for maximizing potential energy generation by anaerobic digestion, costs associated with transporting small amounts of sludge to central collection nodes may not be economically viable. Similarly, more work is needed on sludge issues, especially modeling different scenarios to determine whether maximizing or minimizing sludge production is preferable. Where sludge production is desired, implementation of systems that exploit microbial assimilation may be appropriate.

Strong evidence suggests that a robust and stable microbial community is essential for effective biological P removal, even in small-scale treatment applications. Further, microbial biofilm systems are likely to be more resilient than suspended cultures (Pastorelli et al., 1999; Kodera et al., 2013; Tian et al., 2016), which is particularly important in smaller systems where flows are more variable and less unpredictable than larger systems. However, despite potential benefits associated with biofilms, performance of a nutrient removing algal or mixed culture biofilm over extended periods is neither well understood nor assured (Kesaano and Sims, 2014). This is especially important within the context of variable influent $\mathrm{P}$ concentrations (typical of small-scale systems) and their impact on algal $\mathrm{P}$ uptake under different operating conditions (Boelee et al., 2014). Further investigation is required on up-scaling nutrientremoval biofilm technologies for use at full-scale, specifically with regards to biofilm harvesting and storage/disposal of waste biomass.

Operating costs of the systems described herein has not been discussed at length, primarily due to the lack of available information relating to energy consumption. However, lower energy use and nutrient removal is desirable at all scales, including in small-scale systems. Technologies that require excess aeration and/or mixing are likely to be more energy intensive than technologies that use passive processes, natural energy sources (e.g., sunlight), and biofilms. The energy efficiency and long-term sustainability of nutrient removal systems are important factors about which there appears to be limited comparable information. Further work in this area is critical to operating and policy decisions relative to scaling P-removal options.

Delivering effective $\mathrm{N}$ and $\mathrm{P}$ removal simultaneously appears technically difficult, especially at small-scales where factors such as space limitation and the need for system simplicity means that traditional methods may not work. A few emerging technologies offer some potential in this area, although often at the expense of the simplicity and-or energy requirements for effective operations. At present, the most promising P-removal solution appears to be the use of absorptive media, which is comparatively flexible and integration into a modular system may be suitable for small-scales. The incorporation of media into a constructed wetland appears to offer potential and, in many instances, may present a viable solution to effective $P$ removal at smaller scales, especially where aesthetic considerations must be made. Such systems would have a low operational cost and would generally be easily maintained.

A major disadvantage of adsorption is the P-binding capacity of absorptive materials is finite and, when saturation is reached, replacement is needed (Drizo et al., 1999). As an example, if adsorptive material is incorporated into a wetland, significant capital outlays are needed to sustain system operations. Constructed wetlands are typically land intensive (Machado et al., 2017) and only suitable for locations where population density is low and there is large land availability. Further, disrupting the wetland for media replacement might compromise the system's functionality for carbon and nutrient removal. However, if aesthetic considerations are a priority, land is readily available, and the treatment system is not relied upon for treatment functions other than P-removal (i.e., for tertiary treatment), 
absorptive media and constructed wetlands may be suitable for P-removal at smaller scales.

The progressive refinement of algal biofilm reactors means this option may also have potential. Some algal systems may offer a viable solution for small-scale $\mathrm{N}$ and $\mathrm{P}$ removal if energy needs can be made sustainable and long-term operations can be proven. Further, in locations where climatic condition favor the use of algal systems, some technologies may be suitable for decentralized locations with some modification. In contrast, EBPR-based systems, although well understood, are not likely to be effective at small scales due to the energy, space, capital requirements, and excessive complexity of such systems.

The final factor to consider is the cost-effectiveness of a technology to deliver reliable $\mathrm{P}$ removal. Very little, up to date economic information exists for many technologies described in this review. Most studies to date have considered economic advantages and disadvantages in relation to optimizing specific systems and none focus specifically on small-scale application (e.g., Jiang et al., 2005; Falk et al., 2013). Jiang et al. (2005) found that dosing alum to a conventional activated sludge plant was the most cost-effective solution unless final effluent $\mathrm{P}$ concentrations of $<0.13 \mathrm{mg} / \mathrm{L}$ are required. Under such scenarios, the authors found that a more complex solution becomes cost-effective: EBPR with chemical dosing and filtration. This is likely because of the inability of chemical dosing alone to achieve low $\mathrm{P}$ levels. In a recent study, (Bashar et al., 2018) reviewed the cost-effectivenss of six $\mathrm{P}$ removal and recovery options. The authors concluded that the most cost effective solution was chemical addition to EBPR, unless low $\mathrm{P}$ effluent levels are required. 3-step EBPR with chemical dosing and tertiary filtration delivered $\mathrm{P}$ effluent values of $0.05 \mathrm{mg} / \mathrm{L}$ and cost just $4 \%$ more per $\mathrm{kg}$ of $\mathrm{P}$ removed, than treatment without filtration. The study by Bashar et al. (2018) was the first of its kind that considered such a broad range of technolgies, including less well-established systems. It is, therefore, evident that additional work is required to determine the economic advantages and disadvantages of $\mathrm{P}$ removal technologies in different scenarios. Such studies would allow managers and decision makers to move toward incorporating triple-bottom-line and life-cycle costs into decision making processes.

\section{CONCLUSIONS}

Increasingly stringent requirements on $\mathrm{P}$ removal demand innovative solutions for removing $\mathrm{P}$ from small-scale wastewater treatment works. Promising work has been performed to better understand metabolic pathways associated with luxury P-uptake by bacteria and algae, which provide alternate viable, sustainable and low-cost solution for P removal at smaller scales. However,

\section{REFERENCES}

Acevedo, B., Borras, L., Oehmen, A., and Barat, R. (2014). Modelling the metabolic shift of polyphosphate-accumulating organisms. Water Res. 65, 235-244. doi: 10.1016/j.watres.2014.07.028

Acevedo, B., Oehmen, A., Carvalho, G., Seco, A., Borrás, L., and Barat, R. (2012). Metabolic shift of polyphosphate-accumulating organisms with achieving high levels of $\mathrm{P}$ removal via such systems is often at the expense of system simplicity, particularly in the case of biological treatment options.

There may never be a "one size fits all" technology for Premoval, which is evident when one considers the limited options for small scale treatment applications. A variety of technologies can achieve efficient $\mathrm{P}$ removal, but at the expense of higher energy consumption, increased operational complexity, and-or excessive maintenance. Further, few existing systems have been assessed under variable flow conditions (common in small-scale applications), and some technologies require intense sunlight and-or warm temperatures to be effective; neither prevalent in northern, cooler locales.

Therefore, we conclude that there is a dire shortage of treatment options for $\mathrm{P}$ removal aimed at smaller scales, especially reliable technologies that require minimal maintenance or are suited to northern latitudes. New options are needed that provide a better balance between simplicity, effectiveness and sustainability at smaller scales. The skeleton of possible technologies exist, such as using wetlands incorporating active media which may provide a good starting point for attaining effective and sustainable $\mathrm{P}$ removal in small-scale domestic wastewater treatment systems. However, this is the only technology in which significant progress is being made specifically for small-scale application. We have shown that it may not be appropriate or even possible to down-scale some existing P-removal technologies and expect to maintain the performance that has been proven at large scales. The ecological sensitivity of remote watercourses and the potential for increased regulatory pressure, demands investment in the development of a broader range of small-scale $\mathrm{P}$ removal technologies.

\section{AUTHOR CONTRIBUTIONS}

JB carried out the literature review and wrote the initial draft. EN provided valuable information and text relating to specific technologies. IO assisted with drafting the text and provided expertise relating to the microbiological elements of the manuscript. AM provided industry perspective and insight into current and emerging priorities relating to $\mathrm{P}$ removal at smallscale systems. DG provided over-all guidance of the work and editing of the text.

\section{ACKNOWLEDGMENTS}

This work was supported by the Engineering and Physical Sciences Research Council (EPSRC, award number: EP/M50791X/1) and Northumbrian Water Ltd., which the authors greatly appreciate.

different levels of polyphosphate storage. Water Res. 46, 1889-1900. doi: 10.1016/j.watres.2012.01.003

Achilli, A., Cath, T. Y., Marchand, E. A., and Childress, A. E. (2009). The forward osmosis membrane bioreactor: a low fouling alternative to MBR processes. Desalination 238, 10-21. doi: 10.1016/j.desal.2008.02.022

Arias, C. A., and Brix, H. (2004). Phosphorus removal in constructed wetlands: can a suitable alternative media be identified? Water Sci. Technol. 51, 267-273. 
Arias, C. A., Brix, H., and Johansen, N. H. (2003). Phosphorus removal from municipal wastewater in an experimental two-stage vertical flow constructed wetland system equipped with a calcite filter. Water Sci. Technol. 48, 51-58.

Arnz, P., Arnold, E., and Wilderer, P. A. (2001). Enhanced biological phosphorus removal in a semifull-scale SBBR. Water Sci. Technol. 43, 167-174.

Awual, M. R., and Jyo, A. (2011). Assessing of phosphorus removal by polymeric anion exchangers. Desalination 281, 111-117. doi: 10.1016/j.desal.2011.07.047

Azad, H. S., and Borchardt, J. A. (1970). Variations in phosphorus uptake by algae. Environ. Sci. Technol. 4, 737-743. doi: 10.1021/es60044a008

de-Bashan, L. E., Hernandez, J.-P., Morey, T., and Bashan, Y. (2004). Microalgae growth-promoting bacteria as "helpers" for microalgae: a novel approach for removing ammonium and phosphorus from municipal wastewater. Water Res. 38, 466-474. doi: 10.1016/j.watres.2003.09.022

Bashar, R., Gungor, K., Karthikeyan, K. G., and Barak, P. (2018). Cost effectiveness of phosphorus removal processes in municipal wastewater treatment. Chemosphere doi: 10.1016/j/chemosphere.2017.12.169. [Epub ahead of print]

Bindhu, B. K., and Madhu, G. (2013). Influence of organic loading rates on aerobic granulation process for the treatment of wastewater. J. Clean Energy Technol. 1, 84-87. doi: 10.7763/JOCET.2013.V1.20

Boelee, N. C., Janssen, M., Temmink, H., Shrestha, R., Buisman, C. J. N., and Wijffels, R. H. (2014). Nutrient removal and biomass production in an outdoor pilot-scale phototrophic biofilm reactor for effluent polishing. Appl. Biochem. Biotechnol. 172, 405-422. doi: 10.1007/s12010-013-0478-6

Bowes, M. J., Jarvie, H. P., Halliday, S. J., Skeffington, R. A., Wade, A. J., Loewenthal, M., et al. (2015). Characterising phosphorus and nitrate inputs to a rural river using high-frequency concentration-flow relationships. Sci. Total Environ. 511, 608-620. doi: 10.1016/j.scitotenv.2014.12.086

Brix, H., Arias, C. A., and Bubba, M. (1999). Media selection for sustainable phosphorus removal in subsurface flow constructed wetlands. Water Sci. Technol. 44, 47-54.

Brown, N., and Shilton, A. (2014). Luxury uptake of phosphorus by microalgae in waste stabilisation ponds: current understanding and future direction. Rev. Environ. Sci. Biotechnol. 13, 321-328. doi: 10.1007/s11157-014-9337-3

Burton, F. L., Tchobanoglous, G., Tsuchihashi, R., David Stensel, H., and Metcalf \& Eddy, Inc. (2014). Wastewater Engineering: Treatment and Resource Recovery, 5th Edn. New York, NY: McGraw-Hill.

Carvalheira, M., Oehmen, A., Carvalho, G., and Reis, M. A. M. (2014). Survival strategies of polyphosphate accumulating organisms and glycogen accumulating organisms under conditions of low organic loading. Bioresour. Technol. 172, 290-296. doi: 10.1016/j.biortech.2014.09.059

Chen, L., Gu, Y., Cao, C., Zhang, J., Ng, J. W., and Tang, C. (2014). Performance of a submerged anaerobic membrane bioreactor with forward osmosis membrane for low-strength wastewater treatment. Water Res. 50, 114-123. doi: 10.1016/j.watres.2013.12.009

Chen, Y., Peng, C., Wang, J., Ye, L., Zhang, L., and Peng, Y. (2011). Effect of nitrate recycling ratio on simultaneous biological nutrient removal in a novel anaerobic/anoxic/oxic (A2/O)-biological aerated filter (BAF) system. Bioresour. Technol. 102, 5722-5727. doi: 10.1016/j.biortech.2011.02.114

Childers, D. L., Corman, J., Edwards, M., and Elser, J. M. (2011). Sustainability challenges of phosphorus and food: solutions from closing the human phosphorus cycle. BioScience 61, 117-124. doi: 10.1525/bio.2011/61.2.6

Chong, M. N., Ho, A. N. M., Gardner, T., Sharma, A. K., and Hood, B. (2011). "Assessing decentralised wastewater treatment technologies: Correlating technology selection to system robustness, energy consumption and GHG emission," in International Conference on Integrated Water Management (Perth).

Comeau, Y., Hall, K., Hancock, R., and Oldham, W. (1986). Biochemical model for enhanced biological phosphorus removal. Water Res. 20, 1511-1521. doi: 10.1016/0043-1354(86)90115-6

Cornel, P., and Schaum, C. (2009). Phosphorus recovery from wastewater: needs, technologies and costs. Water Sci. Technol. 59, 1069-1076. doi: 10.2166/wst.2009.045

Crocetti, G. R., Hugenholtz, P., Bond, P. L., Schuler, A. J., Keller, J., Jenkins, D., et al. (2000). Identification of polyphosphate-accumulating organisms and design of 16SrRNA-directed probes for their detection and quantitation. Appl. Environ. Microbiol. 66, 1175-1182. doi: 10.1128/AEM.66.3.11751182.2000
Cydzik-Kwiatkowska, A., and Zielinska, M. (2016). Bacterial communities in fullscale wastewater treatment systems. World J. Microbiol. Biotechnol. 32, 66. doi: 10.1007/s11274-016-2012-9

De-Bashan, L. E., Moreno, M., Hernandez, J. P., and Bashan, Y. (2002). Removal of ammonium and phosphorus ions from synthetic wastewater by the microalgae Chlorella vulgaris coimmobilized in alginate beads with the microalgae growthpromoting bacterium Azospirillum brasilense. Water Res. 36, 2941-2948. doi: 10.1016/S0043-1354(01)00522-X

De Godos, I., González, C., Becares, E., García-Encina, P. A., and Muñoz, R. (2009). Simultaneous nutrients and carbon removal during pretreated swine slurry degradation in a tubular biofilm photobioreactor. Environ. Biotechnol. 82, 187-194. doi: 10.1007/s00253-008-1825-3

De Kreuk, M. K., Heijnen, J. J., and Van Loosdrecht, M. C. M. (2005). Simultaneous COD, nitrogen, and phosphate removal by aerobic granular sludge. Biotechnol. Bioeng. 90, 761-769. doi: 10.1002/bit.20470

Díez-Montero, R., De Florio, L., González-Viar, M., Herrero, M., and Tejero, I. (2016). Performance evaluation of a novel anaerobic-anoxic sludge blanket reactor for biological nutrient removal treating municipal wastewater. Bioresour. Technol. 209, 195-204. doi: 10.1016/j.biortech.2016.02.084

Drizo, A., Forget, C., Chapuis, R. P., and Comeau, Y. (2006). Phosphorus removal by electric arc furnace steel slag and serpentinite. Water Res. 40, 1547-1554. doi: 10.1016/j.watres.2006.02.001

Drizo, A., Frost, C. A., Grace, J., and Smith, K., A. (1999). Physico-chemical screening of phosphate removing substrates for use in constructed wetland systems. Water Res. 33, 3595-3602. doi: 10.1016/S0043-1354(99)00082-2

EA (2015). Water for life and Livelihoods A Consultation on the Draft Update to the River Basin Management Plan Part 2 : River Basin Management Planning Overview and Additional Information. Bristol: EA.

EC (2000). Directive 2000/60/EC of the European Parliament and of the Council of 23 October 2000 establishing a framework for Community action in the field of water policy. Off. J. Eur. Parliam. L327, 1-82. doi: 10.1039/ap9842100196

Falk, M. W., Reardon, D. J., Neethling, J. B., Clark, D. L., and Pramanik, A. (2013). Striking the balance between nutrient removal, greenhouse gas emissions, receiving water quality, and costs. Water Environ. Res. 85, 2307-2316. doi: 10.2175/106143013X13807328848379

Gander, M., Je, B., and Judd, S. (2000). Aerobic MBRs for domestic wastewater treatment : a review with cost considerations. Sep. Purif. Technol. 18, 119-130. doi: 10.1016/S1383-5866(99)00056-8

Gao, F., Yang, Z.-H., Li, C., Zheng, G.-M., Ma, D.-H., and Zhou, L. (2015). A novel algal biofilm membrane photobioreactor for attached microalgae growth and nutrients removal from secondary effluent. Bioresour. Technol. 179, 8-12. doi: 10.1016/j.biortech.2014.11.108

Garcia Martin, H., Ivanova, N., Kunin, V., Warnecke, F., Barry, K. W., McHardy, A. C., et al. (2006). Metagenomic analysis of two enhanced biological phosphorus removal (EBPR) sludge communities. Nat. Biotechnol. 24, 1263-1269. doi: $10.1038 /$ nbt1247

Garzon-Zuniga, M. A., and Gonzalez-Martinez, S. (1996). Biological phosphate and nitrogen removal in a biofilm sequencing batch reactor. Water Sci. Technol. 34, 293-301.

Gieseke, A., Arnz, P., Amann, R., and Schramm, A. (2002). Simultaneous $\mathrm{P}$ and $\mathrm{N}$ removal in a sequencing batch biofilm reactor: insights from reactor- and microscale investigations. Water Res. 36, 501-509. doi: 10.1016/S0043-1354(01)00232-9

Gilmour, D., Blackwood, D., Comber, S., and Thornell, A. (2008). "Identifying human waste contribution of phosphorus loads to domestic wastewater," in Preceedings at the 11th International Conference on Urban Drainage, Held in Edinburgh, (Scoltand), 1-10.

Glemser, M., Heining, M., Schmidt, J., Becker, A., Garbe, D., Buchholz, R., et al. (2016). Application of light-emitting diodes (LEDs) in cultivation of phototrophic microalgae: current state and perspectives. Appl. Microbiol. Biotechnol. 100, 1077-1088. doi: 10.1007/s00253-015-7144-6

Gonzalez, L. E., Caizares, R. O., and Baena, S. (1997). Efficiency of ammonia and phosphorus removal from a Colombian agroindustrial wastewater by the microalgae Chlorella vulgaris and Scenedesmus dimorphus. Bioresour. Technol. 60, 259-262. doi: 10.1016/S0960-8524(97)00029-1

Grau, P. (1996). Low cost wastewater treatment. Water Sci. Technol. 33, 39-46.

Günther, S., Trutnau, M., Kleinsteuber, S., Hause, G., Bley, T., Röske, I., et al. (2009). Dynamics of polyphosphate-accumulating bacteria in wastewater 
treatment plant microbial communities detected via DAPI (4',6'-diamidino2- phenylindole) and tetracycline labeling. Appl. Environ. Microbiol. 75, 2111-2121. doi: 10.1128/AEM.01540-08

Gustafsson, J. P., Renman, A., Renman, G., and Poll, K. (2008). Phosphate removal by mineral-based sorbents used in filters for small-scale wastewater treatment. Water Res. 42, 189-197. doi: 10.1016/j.watres.2007.06.058

Gutiérrez, R., Passos, F., Ferrer, I., Uggetti, E., and García, J. (2015). Harvesting microalgae from wastewater treatment systems with natural flocculants: effect on biomass settling and biogas production. Algal Res. 9, 204-211. doi: 10.1016/j.algal.2015.03.010

He, S., and Xue, G. (2010). Algal-based immobilization process to treat the effluent from a secondary wastewater treatment plant (WWTP). J. Hazard. Mater. 178, 895-899. doi: 10.1016/j.jhazmat.2010.02.022

Herrmann, I., Nordqvist, K., Hedström, A., and Viklander, M. (2014). Effect of temperature on the performance of laboratory-scale phosphorus-removing filter beds in on-site wastewater treatment. Chemosphere 117, 360-366. doi: 10.1016/j.chemosphere.2014.07.069

Hoh, D., Watson, S., and Kan, E. (2016). Algal biofilm reactors for integrated wastewater treatment and biofuel production: a review. Chem. Eng. J. 287, 466-473. doi: 10.1016/j.cej.2015.11.062

Huang, L., and Lee, D. J. (2015). Membrane bioreactor: a mini review on recent R\&D works. Bioresour. Technol. 194, 383-388. doi: 10.1016/j.biortech.2015.07.013

Ivanovic, I., and Leiknes, T. O. (2012). The biofi lm membrane bioreactor (BFMBR) - a review. 37, 288-295. doi: 10.1080/19443994.2012.661283

Jabari, P., Munz, G., and Oleszkiewicz, J. A. (2014). Selection of denitrifying phosphorous accumulating organisms in IFAS systems: comparison of nitrite with nitrate as an electron acceptor. Chemosphere 109, 20-27. doi: 10.1016/j.chemosphere.2014.03.002

Jiang, B. F., Beck, M., Cummings, R., Rowles, K., and Russell, D. (2005). Estimation of Costs of Phosphorus Removal in Wastewater Treatment Facilities: Adaptation of Existing Facilities. Water Policy Working Paper, Number 011.

Johir, M. A. H., Nguyen, T. T., Mahatheva, K., Pradhan, M., Ngo, H. H., Guo, W., et al. (2015). Removal of phosphorus by a high rate membrane adsorption hybrid system. Bioresour. Technol. 201, 365-369. doi: 10.1016/j.biortech.2015.11.045

Kesaano, M., Gardner, R. D., Moll, K., Lauchnor, E., Gerlach, R., Peyton, B. M., et al. (2015). Dissolved inorganic carbon enhanced growth, nutrient uptake, and lipid accumulation in wastewater grown microalgal biofilms. Bioresour. Technol. 180, 7-15. doi: 10.1016/j.biortech.2014.12.082

Kesaano, M., and Sims, R. C. (2014). Algal biofilm based technology for wastewater treatment. Algal Res. 5, 231-240. doi: 10.1016/j.algal.2014.02.003

Kodera, H., Hatamoto, M., Abe, K., Kindaichi, T., Ozaki, N., and Ohashi, A. (2013). Phosphate recovery as concentrated solution from treated wastewater by a PAO-enriched biofilm reactor. Water Res. 47, 2025-2032. doi: 10.1016/j.watres.2013.01.027

Krishnaswamy, U., and Muthusamy, M., Perumalasamy (2009). Studies on the efficiency of the removal of phosphate using bacterial consortium for the biotreatment of phosphate wastewater. Eur. J. Appl. Sci. 1, 6-15.

Kuba, T., Murnleitner, E., van Loosdrecht, M. C., and Heijnen, J. J. (1996). A metabolic model for biological phosphorus removal by denitrifying organisms. Biotechnol. Bioeng. 52, 685-695. doi: 10.1002/(SICI)1097-0290(19961220)52:6<685::AID-BIT6>3.0.CO;2-K

Kuba, T., Smolders, G., van Loosdrecht, M. C. M., and Heijnen, J. J. (1993). Biological phosphorus removal from wastewater by anaerobic-anoxic sequencing batch reactor. Water Sci. Technol. 27, 241-252.

Lanham, A. B., Oehmen, A., Saunders, A. M., Carvalho, G., Nielsen, P. H., and Reis, M. A. M. (2013). Metabolic versatility in full-scale wastewater treatment plants performing enhanced biological phosphorus removal. Water Res. 47, 7032-7041. doi: 10.1016/j.watres.2013.08.042

Larsdotter, K. (2006). Wastewater treatment with microalgae-a literature review. Vatten 62, 31-38.

Le-Clech, P., Chen, V., and Fane, T. A. G. (2006). Fouling in membrane bioreactors used in wastewater treatment. J. Memb. Sci. 284, 17-53. doi: 10.1016/j.memsci.2006.08.019

Le Corre, K. S., Valsami-Jones, E., Hobbs, P., and Parsons, S. A. (2009). Phosphorus recovery from wastewater by struvite crystallisation: a review. Crit. Rev. Environ. Sci. Technol. 39, 433-477. doi: 10.1080/10643380701640573
Lettinga, G., van Velsen, A. F. M., Hobma, S. W., de Zeeuw, W., and Klapwijk, A. (1980). Use of the upflow sludge blanket (USB) reactor concept for biological wastewater treatment, especially for anaerobic treatment. Biotechnol. Bioeng. 22, 699-734. doi: 10.1002/bit.260220402

Li, J., Xing, X. H., and Wang, B. Z. (2003). Characteristics of phosphorus removal from wastewater by biofilm sequencing batch reactor (SBR). Biochem. Eng. J. 16, 279-285. doi: 10.1016/S1369-703X(03)00071-8

López-Vázquez, C. M., Hooijmans, C. M., Brdjanovic, D., Gijzen, H. J., and van Loosdrecht, M. C. M. (2008). Factors affecting the microbial populations at full-scale enhanced biological phosphorus removal (EBPR) wastewater treatment plants in The Netherlands. Water Res. 42, 2349-2360. doi: 10.1016/j.watres.2008.01.001

Luo, W., Hai, F. I., Price, W. E., and Ngheim, L. D. (2015). Water extraction from mixed liquor of an aerobic bioreactor by forward osmosis: membrane fouling and biomass characteristics assessment. Sep. Purif. Technol. 145, 56-62. doi: 10.1016/j.seppur.2015.02.044

Luo, W., Yang, C., He, H., Zeng, G., Yan, S., and Cheng, Y. (2014). Novel two-stage vertical flow biofilter system for efficient treatment of decentralized domestic wastewater. Ecol. Eng. 64, 415-423. doi: 10.1016/j.ecoleng.2014.01.011

Lutterbeck, C. A., Kist, L. T., Lopez, D. R., Zerwes, F. V., and Machado, Ê. L. (2017). Life cycle assessment of integrated wastewater treatment systems with constructed wetlands in rural areas. J. Clean. Prod. 148, 527-536. doi: 10.1016/j.jclepro.2017.02.024

Machado, A. I., Beretta, M., Fragoso, R., and Duarte, E. (2017). Overview of the state of the art of constructed wetlands for decentralized wastewater management in Brazil. J. Environ. Manage. 187, 560-570. doi: 10.1016/j.jenvman.2016.11.015

Majed, N., Chernenko, T., Diem, M., and Gu, A. Z. (2012). Identi fi cation of functionally relevant populations in enhanced biological phosphorus removal processes based on intracellular polymers pro fi les and insights into the metabolic diversity and heterogeneity. Environ. Sci. Technol. 46, 5010-5017. doi: $10.1021 /$ es300044h

Mann, R., and Bavor, H. (1993). Phosphorus removal in constructed wetlands using gravel and industrial-waste substrata. Water Sci. Technol. 27, 107-113.

Mao, Y., Graham, D. W., Tamaki, H., and Zhang, T. (2015). Dominant and novel clades of Candidatus Accumulibacter phosphatis in 18 globally distributed fullscale wastewater treatment plants. Sci. Rep. 5:11857. doi: 10.1038/srep11857

Martin, B. D., Parsons, S. A., and Jefferson, B. (2009). Removal and recovery of phosphate from municipal wastewaters using a polymeric anion exchanger bound with hydrated ferric oxide nanoparticles. Water Sci. Technol. 60, 2637. doi: $10.2166 /$ wst.2009.686

Martínez, M. (2000). Nitrogen and phosphorus removal from urban wastewater by the microalga Scenedesmus obliquus. Bioresour. Technol. 73, 263-272. doi: 10.1016/S0960-8524(99)00121-2

Martin, K. J., and Nerenberg, R. (2012). The membrane biofilm reactor (MBfR) for water and wastewater treatment: principles, applications, and recent developments. Bioresour. Technol. 122, 83-94. doi: 10.1016/j.biortech.2012.02.110

Massoud, M. A., Tarhini, A., and Nasr, J. A. (2009). Decentralized approaches to wastewater treatment and management: applicability in developing countries. J. Environ. Manage. 90, 652-659. doi: 10.1016/j.jenvman.2008.07.001

May, L., Place, C., O'Malley, M., and Spears, B. (2015). The Impact of Phosphorus Inputs from Small Discharges on Designated Freshwater Sites. Natural England Commissioned Reports, Number 170. Worcester, UK.

Mielcarek, A., Rodziewicz, J., Janczukowicz, W., and Thornton, A. (2015). The feasibility of citric acid as external carbon source for biological phosphorus removal in a sequencing batch biofilm reactor (SBBR). Biochem. Eng. J. 93, 102-107. doi: 10.1016/j.bej.2014.10.001

Min, M., Wang, L., Li, Y., Mohr, M. J., Hu, B., Zhou, W., et al. (2011). Cultivating Chlorella sp. in a pilot-scale photobioreactor using centrate wastewater for microalgae biomass production and wastewater nutrient removal. Appl. Biochem. Biotechnol. 165, 123-137. doi: 10.1007/s12010-011-9238-7

Mino, T., Van Loosdrecht, M. C. M., and Heijnen, J. J. (1998). Microbiology and biochemistry of the enhanced biological phosphate removal process. Water Res. 32, 3193-3207. doi: 10.1016/S0043-1354(98)00129-8

Mitchell, S. M., and Ullman, J. L. (2016). Removal of Phosphorus, BOD, and Pharmaceuticals by rapid rate sand filtration and ultrafiltration systems. Environ. Eng. 142, 6016006. doi: 10.1061/(ASCE)EE.1943-7870.0001137 
Molinos-Senante, M., Gómez, T., Garrido-Baserba, M., Caballero, R., and SalaGarrido, R. (2014). Assessing the sustainability of small wastewater treatment systems: a composite indicator approach. Sci. Total Environ. 497, 607-617. doi: 10.1016/j.scitotenv.2014.08.026

Monclus, H., Sipma, J., Ferrero, G., Rodriguez-Roda, I., and Comas, J. (2010). Biological nutrient removal in an MBR treating municipal wastewater with special focus on biological phosphorus removal. Bioresour. Technol. 101, 3984-3991. doi: 10.1016/j.biortech.2010.01.038

Morgenroth, E., and Wilderer, P. A. (1999). Controlled biomass removal-the key parameter to achieve enhanced biological phosphorus removal in biofilm systems. Water Sci. Technol. 39, 33-40.

Nerenberg, R. (2016). The membrane-biofilm reactor (MBfR) as a counterdiffusional biofilm process. Curr. Opin. Biotechnol. 38, 131-136. doi: 10.1016/j.copbio.2016.01.015

Nesbitt, J. (1969). Phosphorus removal: the state of the art. Water Pollut. Control Fed. 41, 701-713.

Ng, W. J., Ong, S. L., Gomez, M. J., Hu, J. Y., and Fan, X. J. (2000). Study on a sequencing batch membrane bioreactor for wastewater treatment. Water Sci. Technol. 41, 227-234.

Nguyen, H. T. T., Le, V. Q., Hansen, A. A., Nielsen, J. L., and Nielsen, P. H. (2011). High diversity and abundance of putative polyphosphate-accumulating Tetrasphaera-related bacteria in activated sludge systems. FEMS Microbiol. Ecol. 76, 256-267. doi: 10.1111/j.1574-6941.2011.01049.x

Nguyen, T. T., Ngo, H. H., and Guo, W. (2013). Pilot scale study on a new membrane bioreactor hybrid system in municipal wastewater treatment. Bioresour. Technol. 141, 8-12. doi: 10.1016/j.biortech.2013.03.125

Nicholls, H. A., and Osborn, D. W. (1979). Bacterial stress: prerequisite for biological removal of phosphorus. J. Water Pollut. Control Fed. 51, 557-569.

Oehmen, A., Lemos, P. C., Carvalho, G., Yuan, Z., Keller, J., Blackall, L. L., et al. (2007). Advances in enhanced biological phosphorus removal: from micro to macro scale. Water Res. 41, 2271-2300. doi: 10.1016/j.watres.2007.02.030

Oleszkiewicz, J., Kruk, D. J., Devlin, T., Lashkarizadeh, M., and Yuan, Q. (2015). Options for Improved Nutrient Removal and Recovery from Municipal Wastewater in the Canadian Context. Winnipeg, MN: Canadian Water Network.

Parsons, S. A., and Smith, J. A. (2008). Phosphorus removal and recovery from municipal wastewaters. Elements 4, 109-112. doi: 10.2113/GSELEMENTS.4.2.109

Pastorelli, G., Canziani, R., Pedrazzi, L., and Rozzi, A. (1999). Phosphorus and nitrogen removal in moving-bed sequencing batch biofilm reactors. Water Sci. Technol. 40, 169-176.

Powell, N., Shilton, A., Chisti, Y., and Pratt, S. (2009). Towards a luxury uptake process via microalgae - Defining the polyphosphate dynamics. Water Res. 43, 4207-4213. doi: 10.1016/j.watres.2009.06.011

Praveen, P., and Loh, K.-C. (2016). Nitrogen and phosphorus removal from tertiary wastewater in an osmotic membrane photobioreactor. Bioresour. Technol. 206, 180-187. doi: 10.1016/j.biortech.2016.01.102

Pronk, M., de Kreuk, M. K., de Bruin, B., Kamminga, P., Kleerebezem, R., and van Loosdrecht, M. C. M. (2015). Full scale performance of the aerobic granular sludge process for sewage treatment. Water Res. 84, 207-217. doi: 10.1016/j.watres.2015.07.011

Rahimi, Y., Torabian, A., Mehrdadi, N., and Shahmoradi, B. (2011). Simultaneous nitrification-denitrification and phosphorus removal in a fixed bed sequencing batch reactor (FBSBR). J. Hazard. Mater. 185, 852-857. doi: 10.1016/j.jhazmat.2010.09.098

Ramanan, R., Kim, B.-H., Cho, D.-H., Oh, H.-M., and Kim, H.-S. (2016). Algaebacteria interactions: evolution, ecology and emerging applications. Biotechnol. Adv. 34, 14-29. doi: 10.1016/j.biotechadv.2015.12.003

Reddy, K. R., DeLaune, R., and Craft, C. B. (2010). Nutrients in Wetlands: Implications to Water Quality under Changing Climatic Conditions. Final Report submitted to U. S. Environmental Protection Agency.

Renman, A., and Renman, G. (2010). Long-term phosphate removal by the calcium-silicate material Polonite in wastewater filtration systems. Chemosphere 79, 659-664. doi: 10.1016/j.chemosphere.2010.02.035

Ruiz-Martinez, A., Martin Garcia, N., Romero, I., Seco, A., and Ferrer, J. (2012). Microalgae cultivation in wastewater: nutrient removal from anaerobic membrane bioreactor effluent. Bioresour. Technol. 126, 247-253. doi: 10.1016/j.biortech.2012.09.022
Sendrowski, A., and Boyer, T. H. (2013). Phosphate removal from urine using hybrid anion exchange resin. Desalination 322, 104-112. doi: 10.1016/j.desal.2013.05.014

Seo, Y. I., Hong, K. H., Kim, S. H., Chang, D., Lee, K. H., and Kim, Y., Do (2013). Phosphorus removal from wastewater by ionic exchange using a surface-modified Al alloy filter. J. Ind. Eng. Chem. 19, 744-747. doi: 10.1016/j.jiec.2012.11.008

Seviour, R. J., Mino, T., and Onuki, M. (2003). The microbiology of biological phosphorus removal in activated sludge systems. FEMS Microbiol. Rev. 27, 99-127. doi: 10.1016/S0168-6445(03)00021-4

Shi, J., Podola, B., and Melkonian, M. (2007). Removal of nitrogen and phosphorus from wastewater using microalgae immobilized on twin layers: an experimental study. J. Appl. Phycol. 19, 417-423. doi: 10.1007/s10811-0069148-1

Shilton, A. N., Elmetri, I., Drizo, A., Pratt, S., Haverkamp, R. G., and Bilby, S. C. (2006). Phosphorus removal by an "active" slag filter-a decade of full scale experience. Water Res. 40, 113-118. doi: 10.1016/j.watres.2005. 11.002

Shin, C., McCarty, P. L., Kim, J., and Bae, J. (2014). Pilot-scale temperateclimate treatment of domestic wastewater with a staged anaerobic fluidized membrane bioreactor (SAF-MBR). Bioresour. Technol. 159, 95-103. doi: 10.1016/j.biortech.2014.02.060

Smith, S., Kim, G., Doan, L., and Roh, H. (2014). Improving biological phosphorus removal in membrane bioreactors - a pilot study. Water Reuse Desalin. 4, 25-33. doi: 10.2166/wrd.2013.119

Smith, A. L., Stadler, L. B., Love, N. G., Skerlos, S. J., and Raskin, L. (2012). Perspectives on anaerobic membrane bioreactor treatment of domestic wastewater: a critical review. Bioresour. Technol. 122, 149-159. doi: 10.1016/j.biortech.2012.04.055

Smolders, G. J. F., van der Meij, J., van Loosdrecht, M. C. M., and Heijnen, J. J. (1994). Model of the anaerobic metabolism of the biological phosphorus removal process: stoichiometry and $\mathrm{pH}$ influence. Biotechnol. Bioeng. 43, 461-470. doi: 10.1002/bit.260430605

Smolders, G. J. F., van Loosdrecht, M. C. M., and Heijnen, J. J. (1995). A metabolic model for the biological phosphorus removal process. Water Sci. Technol. 31, 79-93.

Sukacova, K., Trtílek, M., and Rataj, T. (2015). Phosphorus removal using a microalgal biofilm in a new biofilm photobioreactor for tertiary wastewater treatment. Water Res. 71, 55-63. doi: 10.1016/j.watres.2014.12.049

Sun, F. Y., Wang, X. M., and Li, X. Y. (2013). An innovative membrane bioreactor (MBR) system for simultaneous nitrogen and phosphorus removal. Process Biochem. 48, 1749-1756. doi: 10.1016/j.procbio.2013.08.009

Sun, L., Wang, Z., Wei, X., Li, P., Zhang, H., Li, M., et al. (2015). Enhanced biological nitrogen and phosphorus removal using sequencing batch membrane-aerated biofilm reactor. Chem. Eng. Sci. 135, 559-565. doi: 10.1016/j.ces.2015.07.033

Tian, Q., Ong, S. K., Xie, X., Li, F., Zhu, Y., Wang, F. R., et al. (2016). Enhanced phosphorus recovery and biofilm microbial community changes in an alternating anaerobic/aerobic biofilter. Chemosphere 144, 1797-1806. doi: 10.1016/j.chemosphere.2015.10.072

UKTAG (2013). Updated Recommendations on Phosphorus Standards for. UKTAG, $1-13$.

Vohla, C., Kõiv, M., Bavor, H. J., Chazarenc, F., and Mander, Ü. (2011). Filter materials for phosphorus removal from wastewater in treatment wetlands-A review. Ecol. Eng. 37, 70-89. doi: 10.1016/j.ecoleng.2009.08.003

Vymazal, J. (2007). Removal of nutrients in various types of constructed wetlands. Sci. Total Environ. 380, 48-65. doi: 10.1016/j.scitotenv.2006.09.014

Wang, D., Guo, F., Wu, Y., Li, Z., and Wu, G. (2018). Technical, economic and environmental assessment of coagulation/filtration tertiary treatment processes in full-scale wastewater treatment plants. J. Clean. Prod. 170, 1185-1194. doi: 10.1016/j.jclepro.2017.09.231

Wang, X. J., Xia, S. Q., Chen, L., Zhao, J. F., Renault, N. J., and Chovelon, J. M. (2006). Nutrients removal from municipal wastewater by chemical precipitation in a moving bed biofilm reactor. Process Biochem. 41, 824-828. doi: 10.1016/j.procbio.2005.10.015

Wei, Q., Hu, Z., Li, G., Xiao, B., Sun, H., and Tao, M. (2008). Removing nitrogen and phosphorus from simulated wastewater using algal biofilm technique. Front. Environ. Sci. Eng. China 2, 446-451. doi: 10.1007/s11783-008-0064-2 
Wentzel, M. C., Lotter, L. H., Loewenthal, R. E., and Marais, G. (1986). Metabolic behaviour or Acinetobacter spp. in enhanced biological phosphorus removal-a biochemical model. Water SA 12, 209-224.

Whalley, M., Laidlaw, S., Steel, P., and Shiskowski, D. (2013). Meeting ultra-low effluent phosphorus in small, cold-climate WWTFs. Proc. Water Environ. Fed. 2013, 213-217. doi: 10.2175/193864713813525338

Xu, M., Bernards, M., and Hu, Z. (2014). Algae-facilitated chemical phosphorus removal during high-density Chlorella emersonii cultivation in a membrane bioreactor. Bioresour. Technol. 153, 383-387. doi: 10.1016/j.biortech.2013.12.026

Yang, S., Yang, F., Fu, Z., Wang, T., and Lei, R. (2010). Simultaneous nitrogen and phosphorus removal by a novel sequencing batch moving bed membrane bioreactor for wastewater treatment. J. Hazard. Mater. 175, 551-557. doi: 10.1016/j.jhazmat.2009.10.040

Yeoman, S., Stephenson, T., Lester, J. N., and Perry, R. (1988). The removal of phosphorus during wastewater treatment: a review. Environ. Pollut. 49, 183-233. doi: 10.1016/0269-7491(88)90209-6

Yin, H., Yan, X., and Gu, X. (2017). Evaluation of thermally-modified calciumrich attapulgite as a low-cost substrate for rapid phosphorus removal in constructed wetlands. Water Res. 115, 329-338. doi: 10.1016/j.watres.2017. 03.014

Yin, J., Zhang, P., Li, F., Li, G., and Hai, B. (2015). Simultaneous biological nitrogen and phosphorus removal with a sequencing batch reactor-biofilm system. Int. Biodeterior. Biodegradation 103, 221-226. doi: 10.1016/j.ibiod.2015. 02.019

Zeng, R. J., Saunders, A. M., Yuan, Z., Blackall, L. L., and Keller, J. (2003). Identification and comparison of aerobic and denitrifying polyphosphate-accumulating organisms. Biotechnol. Bioeng. 83, 140-148. doi: 10.1002/bit.10652

Zhang, X., Li, D., Liang, Y., Zeng, H., He, Y., Zhang, Y., et al. (2014). Performance and microbial community of completely autotrophic nitrogen removal over nitrite (CANON) process in two membrane bioreactors (MBR) fed with different substrate levels. Bioresour. Technol. 152, 185-191. doi: 10.1016/j.biortech.2013.10.110

Zhao, D., and Sengupta, A. K. (1998). Ultimate removal of phosphate from wastewater using a new class of polymeric ion exchangers. Water Res. 32, 1613-1625. doi: 10.1016/S0043-1354(97)00371-0

Zhou, Y., Pijuan, M., Zeng, R. J., and Yuan, Z. (2009). Involvement of the TCA cycle in the anaerobic metabolism of polyphosphate accumulating organisms (PAOs). Water Res. 43, 1330-1340. doi: 10.1016/j.watres.2008.12.008

Conflict of Interest Statement: The authors declare that the research was conducted in the absence of any commercial or financial relationships that could be construed as a potential conflict of interest.

The reviewer AM and handling editor declared their shared affiliation.

Copyright (C) 2018 Bunce, Ndam, Ofiteru, Moore and Graham. This is an open-acces article distributed under the terms of the Creative Commons Attribution License (CC $B Y)$. The use, distribution or reproduction in other forums is permitted, provided the original author(s) and the copyright owner are credited and that the original publication in this journal is cited, in accordance with accepted academic practice. No use, distribution or reproduction is permitted which does not comply with these terms. 